\title{
KARAKTERISTIK ALTERASI DAN MINERALISASI HIDROTERMAL DAERAH HULAWA, GORONTALO, INDONESIA
}

\author{
Umar Zulkarnain Bakkar ${ }^{\mathrm{a}}$, Muhammad Kasima ${ }^{\mathrm{a}}$, Noviar Akase ${ }^{\mathrm{a}}$, Ahmad Iryanto Rompo \\ ${ }^{a}$ Teknik Geologi, Universitas Negeri Gorontalo, Jl. Jendral Sudirman No.6, Kota Gorontalo, 96128, Indonesia \\ ${ }^{b}$ PT. Gorontalo Sejahtera Mining, Jl. Jend. Sudirman, Jakarta, 12190, Indonesia
}

\section{INFO ARTIKEL}

\section{Status artikel:}

Diterima: 24 Juli 2019

Disetujui: 20 September 2019

Tersedia online: 25 Januari 2020

\section{Kata kunci:}

Alteration; Hulawa; Low Sulphidation Epithermal; Mineralization

\section{Penulis korespondensi:}

Umar Zulkarnain Bakkar

Program Studi Teknik Geologi, Jurusan

Ilmu dan Teknologi Kebumian,

Fakultas MIPA, Universitas Negeri

Gorontalo, Indonesia

Email: umarzulkarnainb@gmail.com

\begin{abstract}
Gold is one of the precious metals with high economic value, so the exploration process becomes an important stage to find new resources so that gold production remains optimal. The research was aimed at investigating the geological condition and characteristics of hydrothermal alteration and mineralization developed in the research site. The research site was included in the area CoW of PT. Gorontalo Sejahtera Mining exactly lied in Hulawa Village, Gorontalo, Indonesia. This research integrated the fieldwork with laboratory tests and analysis, including petrography, Analytical Spectral Devices, and mineragraphy. Based on data that had been conducted and data analysis results, it can be concluded that the research site consisted of lithology in the form of Oligocene granodiorite and Pliocene rhyodacite and diatreme breccia that rolled as host rock's mineralization. Normal right-slip fault directing E-W is interpreted as a pre-mineralization structure, while normal leftslip fault directing NNE-SSW is interpreted as syn-mineralization structure or controlling structure during alteration and mineralization process. Alteration developed in research area consisted of the phyllic zone (sericite + quartz \pm pyrite \pm montmorillonite \pm chlorite \pm carbonate), argillic zone (illite + kaolinite \pm smectite \pm montmorilonite), and chloritic zone (chlorite + carbonate + pyrite \pm quartz \pm illite \pm sericite \pm montmorillonite). Hydrothermal deposits controlled by geological structure and volcanic mechanism. Mineralization in the research site was found in stockwork quartz veins and hydrothermal breccia, and some were found in dissemination with ores such as pyrite, chalcopyrite, arsenopyrite, galena, sphalerite, bornite, covelite, gold, and electrum. Based on its alteration and mineralization characteristics, the epithermal deposits in the research site was the type of low sulphidation deposite in-depth level in the model of open-vein and breccia.
\end{abstract}

Copyright $(2020$ JGEOSREV-UNG This open-access article is distributed under $a$ Creative Commons Attribution (CC-BY) 4.0 International license

\section{Pendahuluan}

Mineral bijih terutama emas merupakan salah satu kebutuhan dasar manusia. Seiring dengan berkembangnya zaman, kebutuhan akan sumberdaya mineral bijih pun semakin meningkat. Secara umum mineralisasi dapat terbentuk akibat panas dari larutan hidrotermal yang bereaksi dengan wallrock (batuan samping) di sepanjang rekahan/fracture dan ruang antara butiran/mineral, sehingga terjadi proses alterasi yang mengubah mineral penyusun wallrock, baik itu sifat fisik maupun kimianya (Pirajno, 1992). Tipe alterasi dan mineralisasi pada suatu daerah mempunyai sifat dan karakteristik tersendiri yang sering dicirikan dengan adanya himpunan mineral tertentu. Keberadaan zona alterasi dan mineralisasi ini akan membantu dalam perencanaan pengembangan eksplorasi mineral bijih yang mengandung logam berharga.

Daerah penelitian dan sekitarnya memiliki tipe endapan epitermal sulfidasi rendah yang dikontrol oleh mekanisme vulkanik dan struktur geologi. Mineralisasi emas terdapat pada kombinasi urat kuarsa, breksi dan stockwork (Carlile et al., 1990). 
Pendekatan studi karakteristik alterasi dan mineralisasi menjadi penting untuk diketahui. Atas dasar diatas maka peneliti menilai bahwa daerah ini sangat layak untuk dijadikan lokasi penelitian karakteristik alterasi dan mineralisasi yang nantinya akan berpengaruh terhadap eksplorasi lebih lanjut. Maksud dan tujuan dalam penelitian ini yakni untuk memetakan kondisi geologi serta karakteristik alterasi dan mineralisasinya untuk dapat mengetahui kondisi geologi serta karakteristik alterasi dan mineralisasi hidrotermal yang berkembang pada daerah penelitian.

\section{Metode}

\subsection{Lokasi Penelitian}

Secara administrasi, daerah penelitian terletak di Desa Hulawa, Kecamatan Buntulia, Kabupaten Pohuwato, tepatnya berada pada koordinat $\mathrm{N} 0^{\circ} 35^{\prime} 22,7^{\prime \prime}-\mathrm{N} 0^{\circ} 33^{\prime} 25,9^{\prime \prime}$ dan E $121^{\circ} 59^{\prime} 49,4^{\prime \prime}-122^{\circ}$ 1' 59,1", dengan luas daerah mencapai $14,2 \mathrm{Km}^{2}$ (Gambar 1). Daerah penelitian juga masuk dalam daerah kontrak karya PT. Gorontalo Sejahtera Mining.

Penelitian dibagi menjadi beberapa tahap dan alur penelitian yang terdiri dari tahap persiapan, tahap studi pendahuluan, tahap pengambilan data lapangan, tahap analisis dan pengolahan data, tahap pembahasan, serta tahap penarikan kesimpulan. Pada tahap persiapan, dilakukan pengurusan administrasi dan perizinan serta persiapan alat dan bahan yang akan digunakan dalam pengambilan data lapangan, selanjutnya pada tahap studi pendahuluan, dilakukan studi literatur dari penelitianpenelitian terdahulu terkait lokasi penelitian ataupun kaitannya dengan tema penelitian, juga dilakukan interpretasi geologi serta perencanaan lintasan pengamatan yang berguna untuk mempermudah dalam pengembilan data lapangan. Pada tahap pengambilan data lapangan, dilakukan penentuan lokasi dan deskripsi singkapan untuk mengetahui jenis litologi maupun ciri alterasi dan mineralisasi yang berkembang, serta melakukan sampling dan dokumentasi.

Tahap analisis dan pengolahan data, peneliti membagi kedalam dua kelompok pengolahan data, yakni pengolahan studio yang merupakan pembuatan peta-peta menggunakan softwere ArcGIS 10.3 meliputi pembuatan peta geomorfologi, peta geologi dan peta zona alterasi serta pengolahan data struktur geologi menggunakan softwere Dips 6.0. Pada proses analisis laboratorium, peneliti

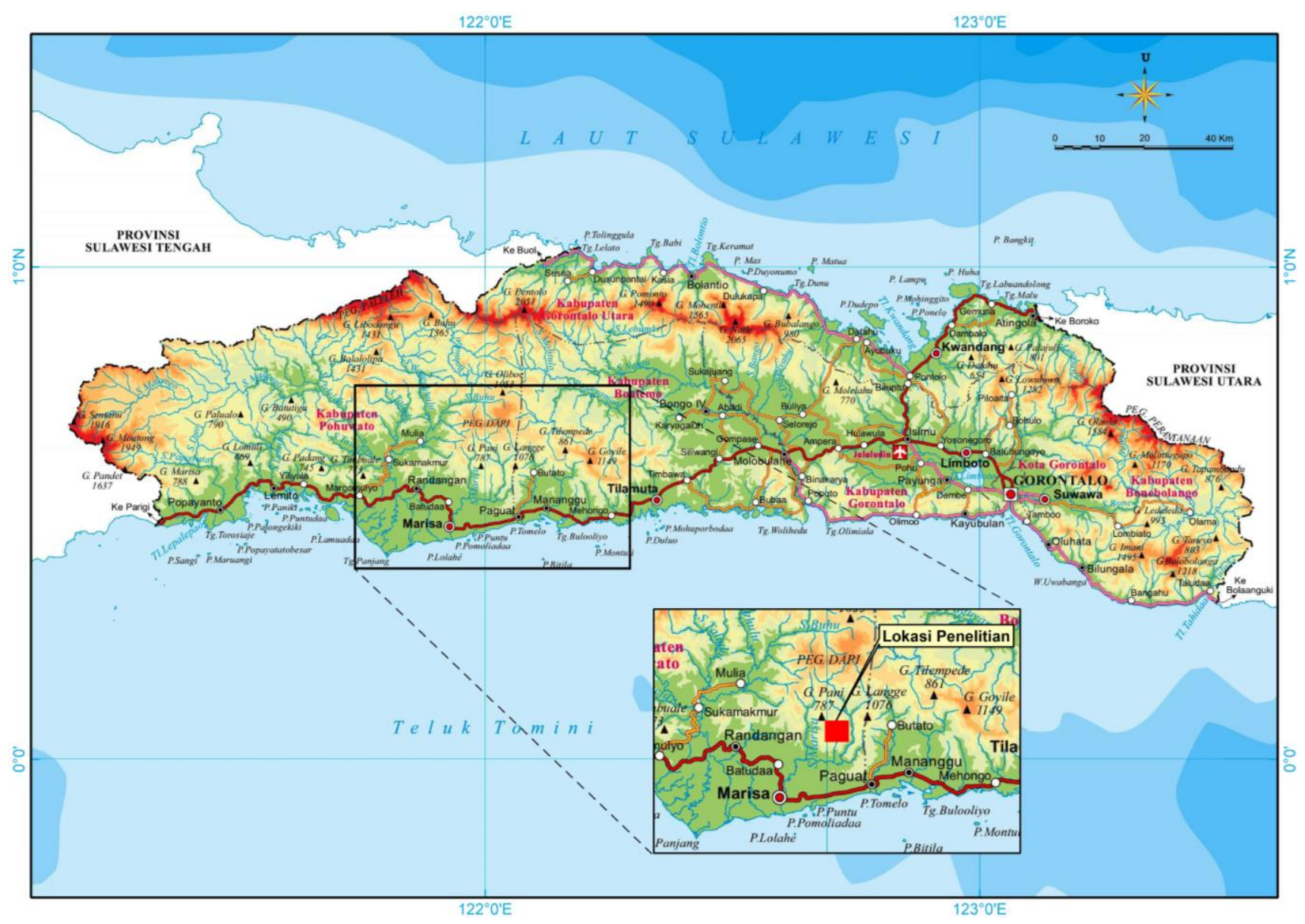

Gambar 1. Peta administrasi daerah penelitian (BIG, 2013) 
melakukan tiga analisis yang terdiri dari analisis petrografi, analisis mineragrafi serta ASD (Analytical Spectral Devices). Pada tahap pembahasan, data primer dan sekunder serta hasil analisa laboratorium yang diperoleh kemudian dikorelasikan dengan dasar teori mengenai tema penelitian. Pada tahap terakhir, dilakukan penarikan interpretasi dan kesimpulan dari tahap sebelumnya.

\subsection{Analisis Petrografi}

Analisis petrografi dilakukan untuk dapat mengetahui dengan jelas, tekstur batuan, serta mineralogi batuan yang nantinya akan digunakan dalam penentuan jenis batuan dan himpunan mineral alterasi. Pengamatan petrografi dilakukan di CV. Obsidian Geo Laboratory Services, Bandung, Jawa Barat, dengan menggunakan mikroskop polarisasi pengamatan nikol silang dan nikol sejajar.

\subsection{Analisis Mineragrafi}

Analisis mineragrafi bertujuan untuk dapat mengetahui jenis serta tekstur dari mineral bijih pada batuan. Pengamatan dilakukan di Laboratorium Geokimia Mineral, Departemen Teknik Geologi, Universitas Hassanudin, Makassar menggunakan mikroskop polarisasi.

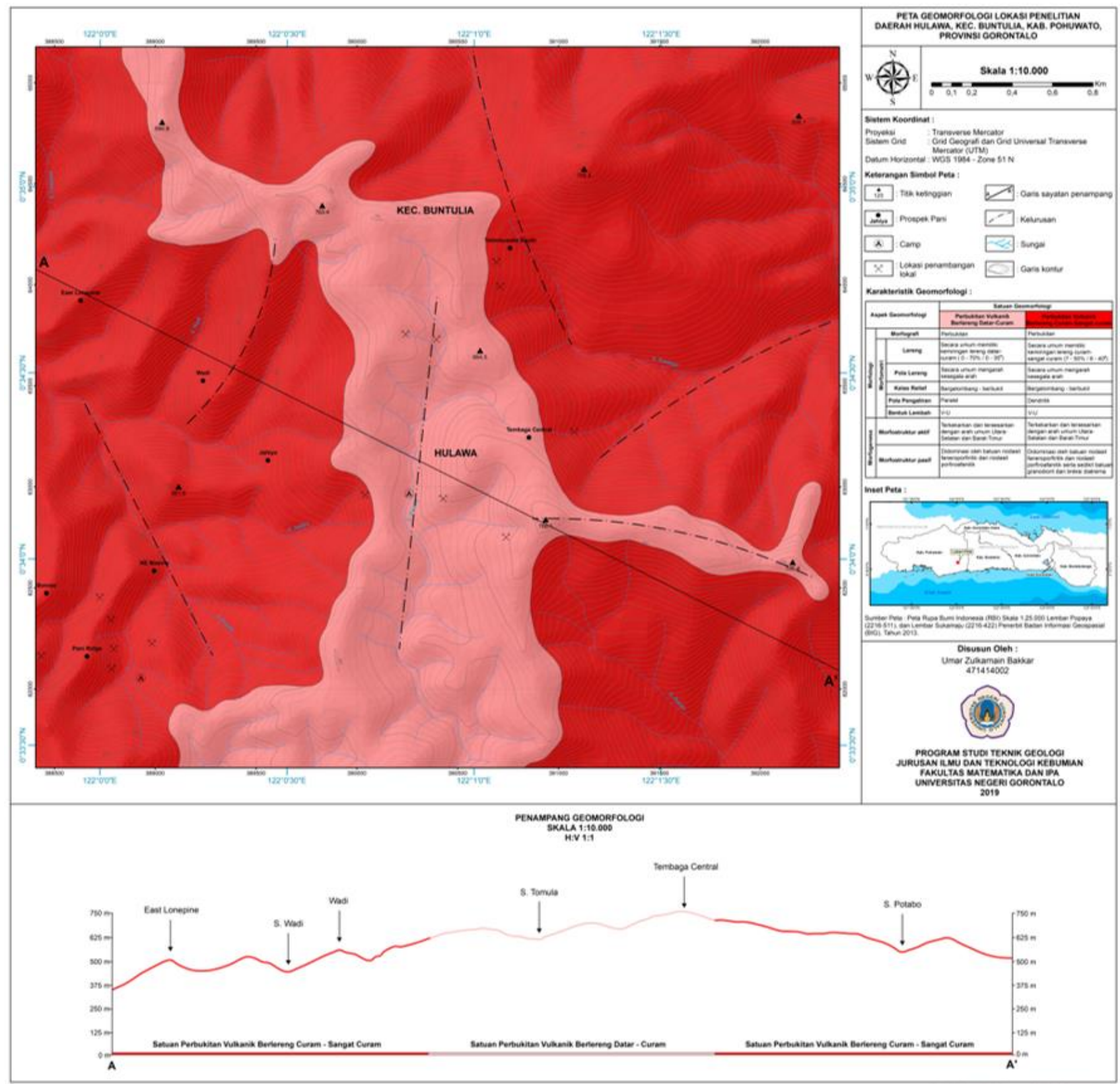

Gambar 2. Peta geomorfologi daerah penelitian 


\subsection{Analisis ASD (Analytical Spectral Devices)}

Analisis ASD dilakukan untuk mengidentifikasi mineral ubahan, terutama mineral lempung yang sulit diidentifikasi menggunakan mikroskop polarisasi, sehingga dapat mendukung dalam penentuan himpunan mineral ubahan. Analisis ini dilakukan di PT. J Resources Nusantara.

\section{Hasil dan Pembahasan}

\subsection{Geologi Daerah Penelitian}

Berdasarkan pengamatan lapangan, daerah penelitian memiliki bentukan geomorfologi vulkanik yang dibagi atas dua sub-satuan geomorfik yang didasarkan pada karakteristik geomorfologi menurut klasifikasi dari van Zuidam (1985) yakni, perbukitan vulkanik berlereng datar sampai curam serta perbukitan vulkanik berlereng curam sampai sangat curam (Gambar 2).

Daerah penelitian disusun oleh litologi berupa granodiorit berumur Oligosen dan satuan riodasit faneroporfiritik dan riodasit porfiroafanitik, serta breksi diatrema berumur Pliosen (Gambar 2 \& 3). Satuan granodiorit ditemukan pada beberapa lokasi di Sungai Lonepine dan Sungai Tembaga. Secara umum satuan ini telah mengalami proses alterasi chloritic yang cukup kuat, ditandai dengan kehadiran mineral klorit yang melimpah menggantikan mineral biotit dan hornblenda. Satuan riodasit merupakan litologi yang mendominasi pada daerah penelitian dengan ciri-ciri berwarna abu-abu, memiliki perbedaan tekstur batuan yakni faneroporfiritik dan porfiroafanitik disusun oleh mineral kuarsa, kfeldspar, plagioklas, biotit dan hornblenda serta sering dijumpai adanya diseminasi pirit. Satuan breksi diatrema memiliki pemilahan buruk serta disusun atas fragmen riodasit serta tuf yang teralterasi, berukuran $0.5-1 \mathrm{~cm}$ dengan bentuk subangular - subrounded, memiliki semen berupa gelas vulkanik (Gambar 3).

Struktur geologi yang berkembang berupa jaringan kekar gerus (shear fracture) dan kekar tarik (gash fracture) dan sesar-sesar berjenis oblique (normal right slip fault dan normal left slip fault) berarah E-W dan NNE-SSW yang diduga berpengaruh terhadap distribusi proses alterasi dan permineralisasian pada daerah penelitian (Gambar 4).

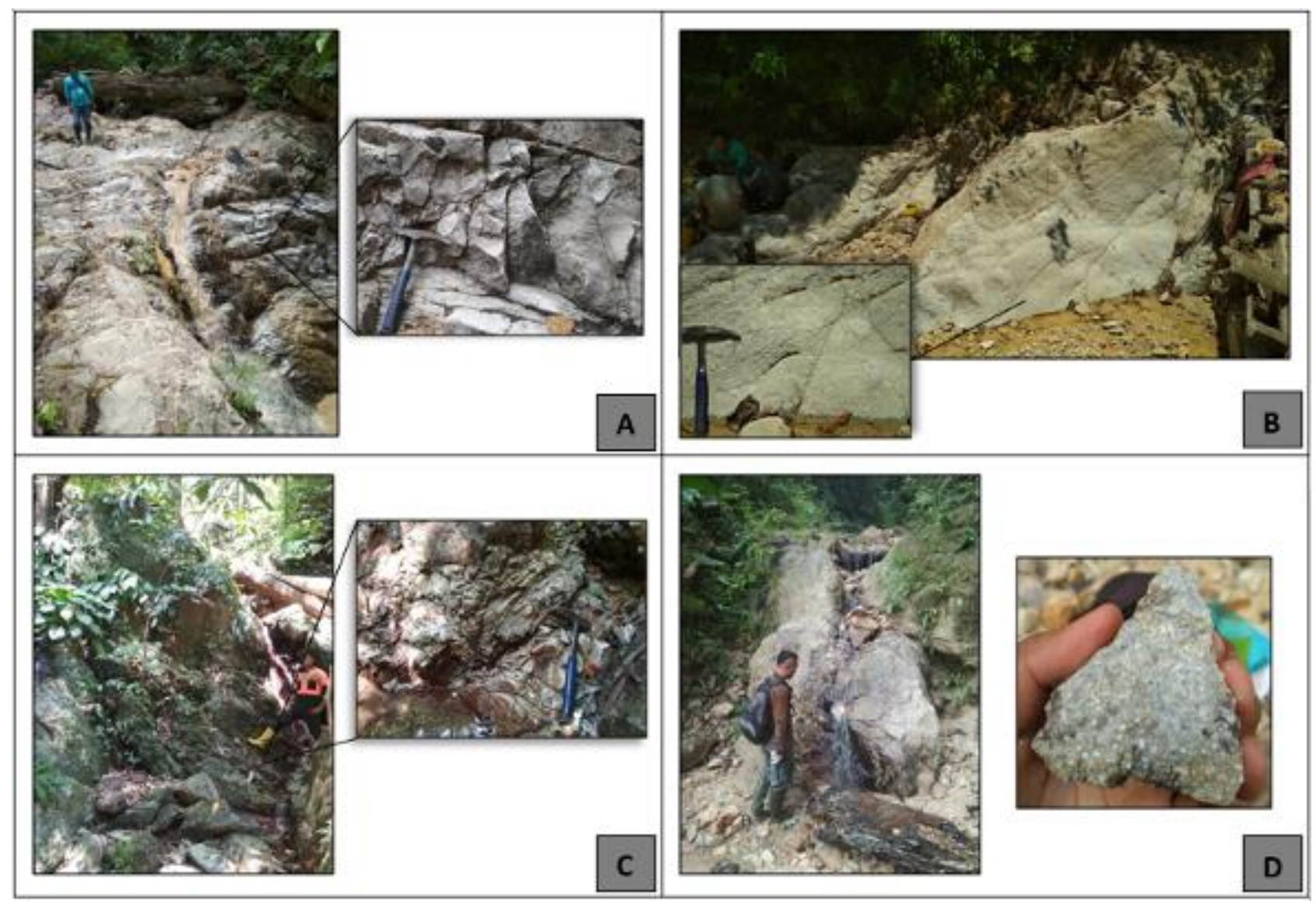

Gambar 3. Satuan litologi pada daerah penelitian. A. Satuan granodiorit, B. Satuan breksi diatrema, C. Satuan riodasit faneroporfiritik, D. Satuan riodasit porfiroafanitik 


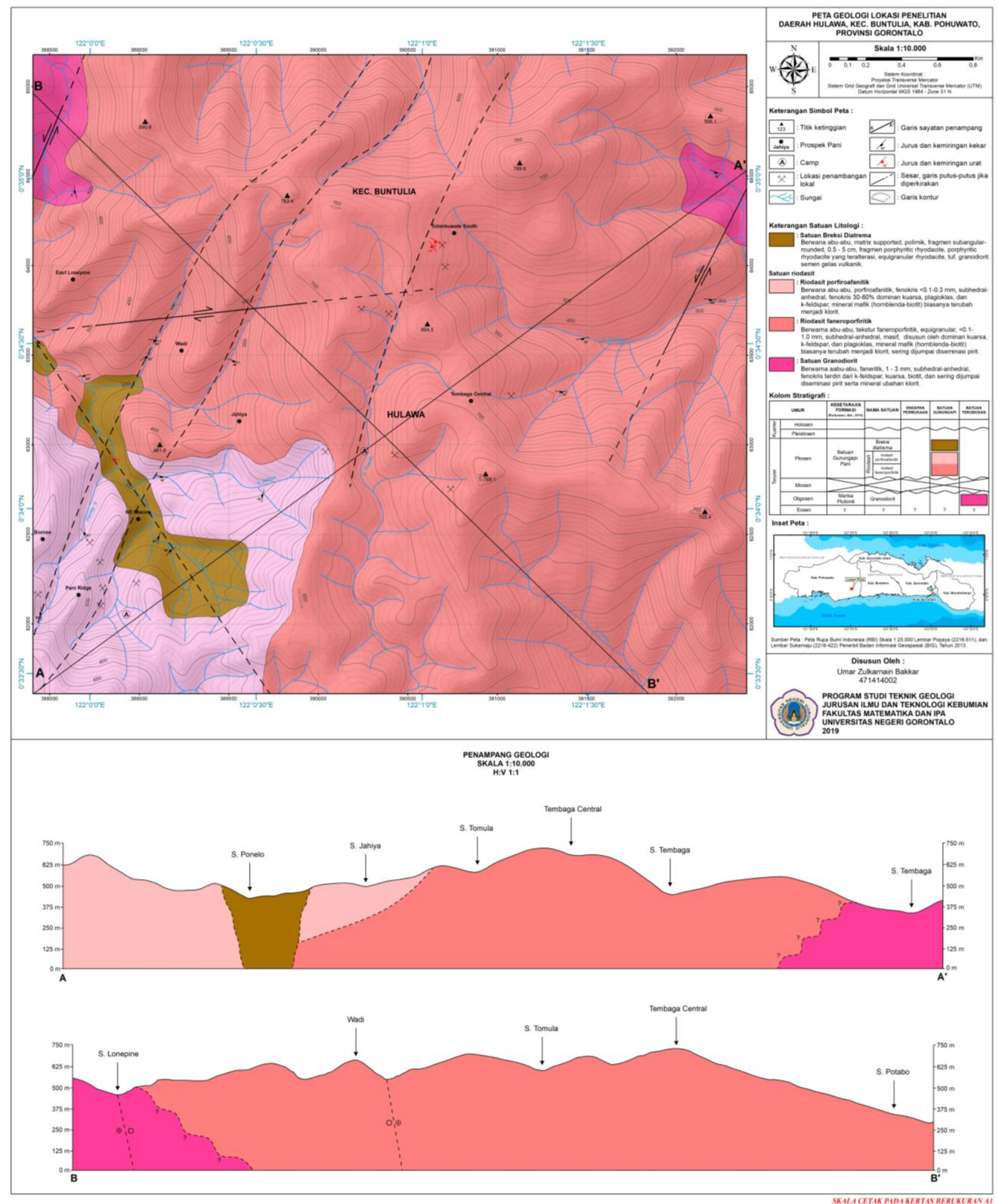

Gambar 4. Peta geologi daerah penelitian

\subsection{Alterasi Hidrotermal}

Daerah penelitian memiliki tiga tipe alterasi yang berkembang berdasarkan himpunan mineral yang teramati di lapangan serta pada pengamatan petrografi dan ASD (Analitycal Spectral Devices), yang setara dengan zona filik (serisit + kuarsa + muskovit \pm pirit \pm monmorilonit \pm klorit \pm smektit), zona argilik (illit + kaolinit \pm smektit \pm monmorilonit), zona chloritic (klorit + karbonat + pirit \pm kuarsa \pm illit \pm serisit \pm monmorilonit) (Gambar 15).

Zona alterasi filik diinterpretasikan menjadi halo untuk pusat dari zonasi alterasi hidrotermal pada daerah penelitian. Zona ini menampati sekitar 20\% dari total luas daerah penelitian. Secara umum alterasi ini banyak berkembang pada satuan riodasit porfiroafanitik dan breksi diatrema. Berdasarkan 
pengamatan petrologi dan petrografi tipe alterasi filik ini dicirikan dengan himpunan mineral serisit, kuarsa, pirit, dan klorit (Gambar 5 \& 6). Pada analisis menggunakan ASD, peneliti menganalisis delapan sampel yang terindikasi teralterasi filik. Hasil analisis didapati himpunan mineral ubahan berupa muskovit, phengitic, klorit, serta nontronit (smectite group) (Tabel 1).

Alterasi argilik pada daerah penelitian berkembang pada satuan riodasit dan breksi diatrema. Zona ini memiliki pelamparan sekitar 30\%. Berdasarkan pengamatan megaskopis alterasi argilik ini dicirikan dengan melimpahnya mineral lempung berwarna putih pada batuan (Gambar 7). Dari hasil analisis menggunakan ASD didapati himpunan mineral lempung berupa illit, halloysite (kaolin group), monmorilonit dan nontronit (smectite group) (Tabel 2).

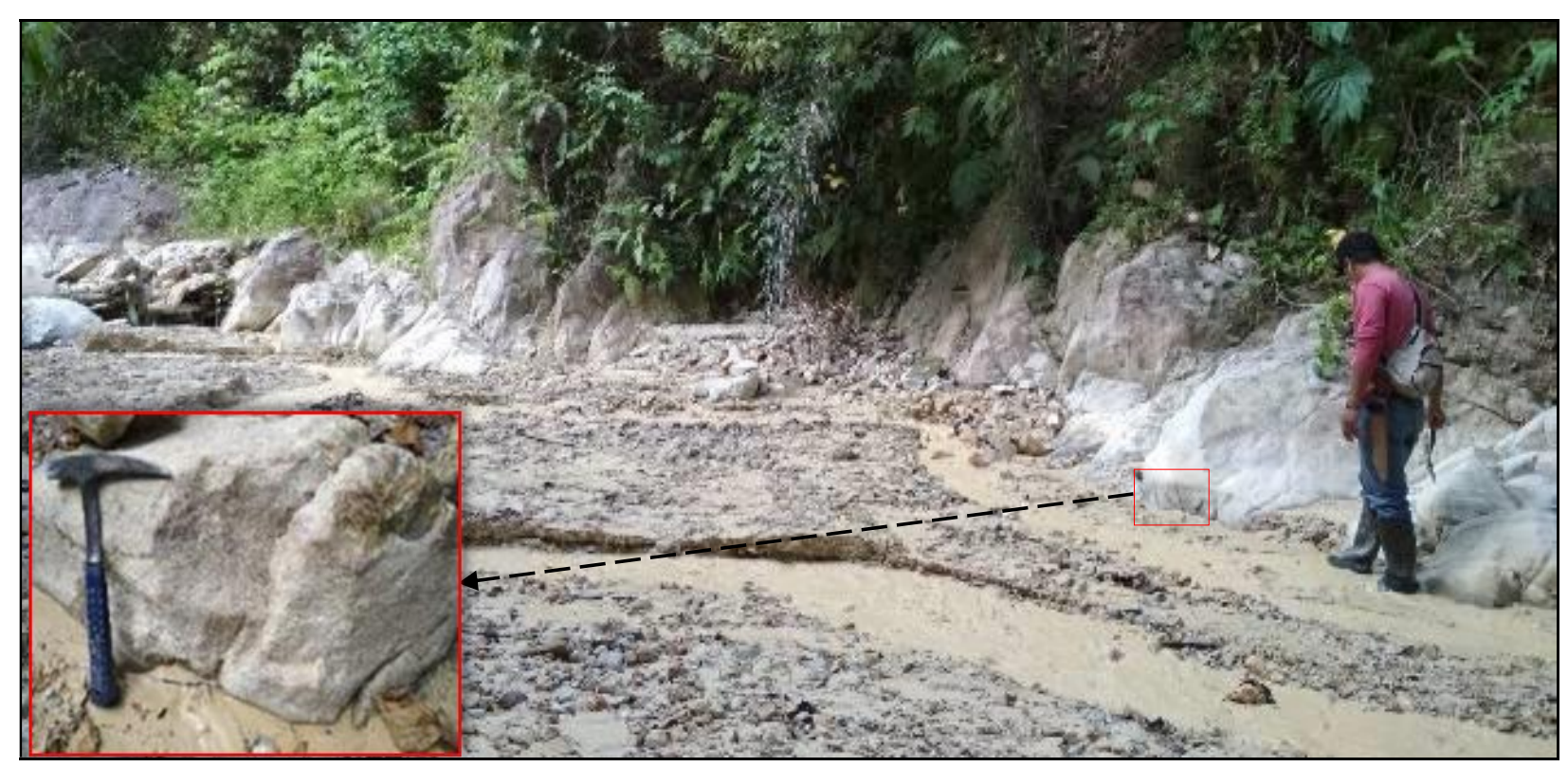

Gambar 5. Singkapan satuan breksi diatrema teralterasi filik
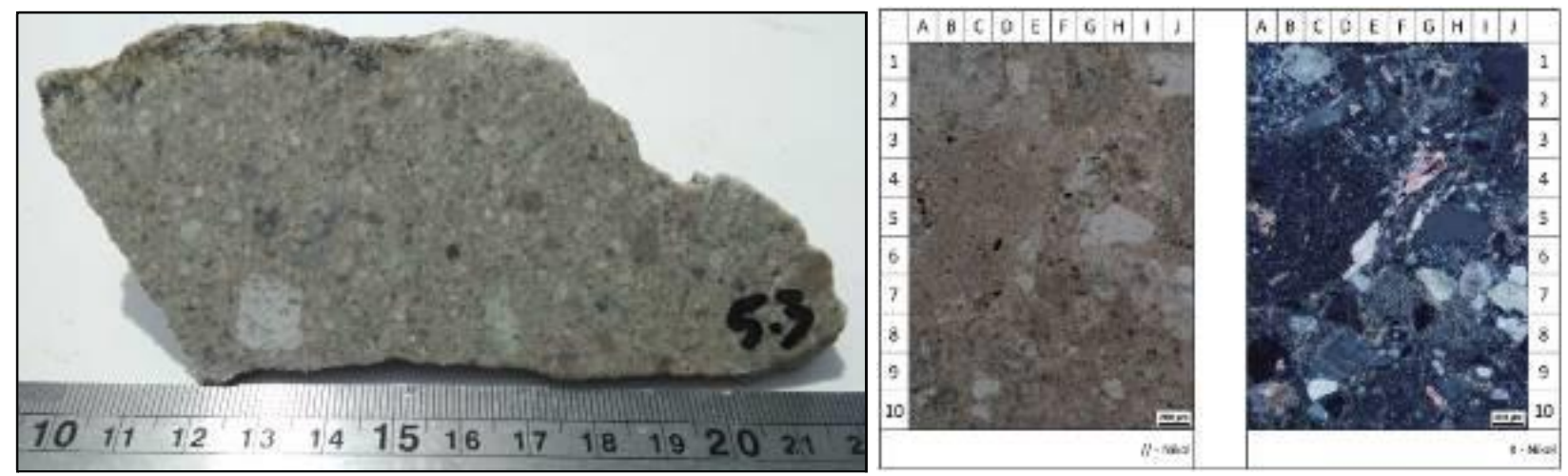

Gambar 6. Kenampakkan mikroskopis breksi diatrema yang telah teralterasi filik

Tabel 1. Hasil analisis Analytical Spectral Devices (ASD) sampel batuan teralterasi filik

\begin{tabular}{llll}
\hline No. & Kode sampel & Mineral 1 & Mineral 2 \\
\hline 1 & 01.5. asd & Muscovitic-Phengitic & Nontronite \\
2 & 05.3. asd & Phengitic & Chlorite \\
3 & 05.4. asd & Muscovitic-Phengitic & Chlorite \\
4 & 06.6. asd & Muscovitic-Phengitic & - \\
5 & 06.7. asd & Muscovitic-Phengitic & - \\
6 & 08.1 asd & Muscovitic-Phengitic & Nontronite \\
7 & 08.2. asd & Muscovitic-Phengitic & Nontronite \\
8 & 11.2.asd & Muscovitic & Nontronite \\
\hline
\end{tabular}




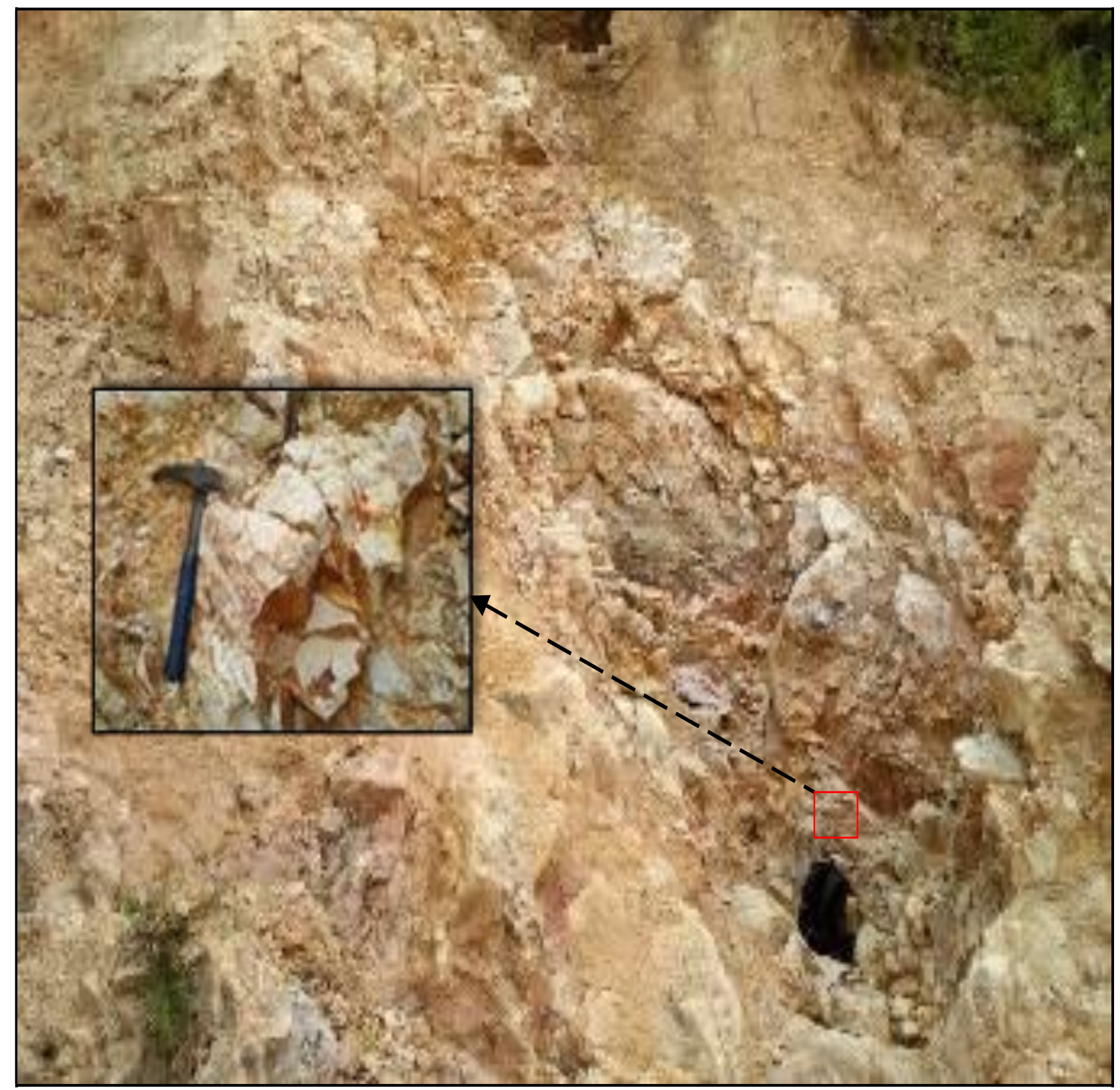

Gambar 7. Singkapan satuan riodasit faneroporfiritik teralterasi argilik

Tabel 2. Hasil analisis Analytical Spectral Devices (ASD) sampel batuan teralterasi argilik

\begin{tabular}{lllll}
\hline No. & Kode sampel & Mineral 1 & Mineral 2 & Mineral 3 \\
\hline 1 & 09.3.asd & Illite & Halloysite & Nontronite \\
2 & 10.1.asd & Montmorilonite & Illite & - \\
3 & 11.1.asd & Illite & Halloysite & Nontronite \\
4 & 17.1.asd & Halloysite & Illite & Nontronite \\
\hline
\end{tabular}

Zona alterasi chloritic pada daerah penelitian merupakan alterasi terluar dari zona alterasi hidrotermal pada daerah penelitian, serta memiliki pelamparan paling luas yakni sekitar $50 \%$ dari total luas daerah penelitian. Secara umum alterasi ini banyak berkembang pada satuan granodiorit dan riodasit faneroporfiritik. Dicirikan dengan warna batuan yang kehijauan dikarenakan melimpahnya mineral klorit disertai dengan karbonat, pirit, kuarsa, serta serisit dilihat secara megaskopis dan petrografi (Gambar 8 \& 9).

Pada analisis menggunakan ASD peneliti menganalisis delapan sampel yang diindikasikan teralterasi chloritic. Hasil analisis didapati himpunan mineral lempung berupa klorit, ilit, muscoviticphengitic (mica group), serta halloysite (kaolin group) (Tabel 3). 


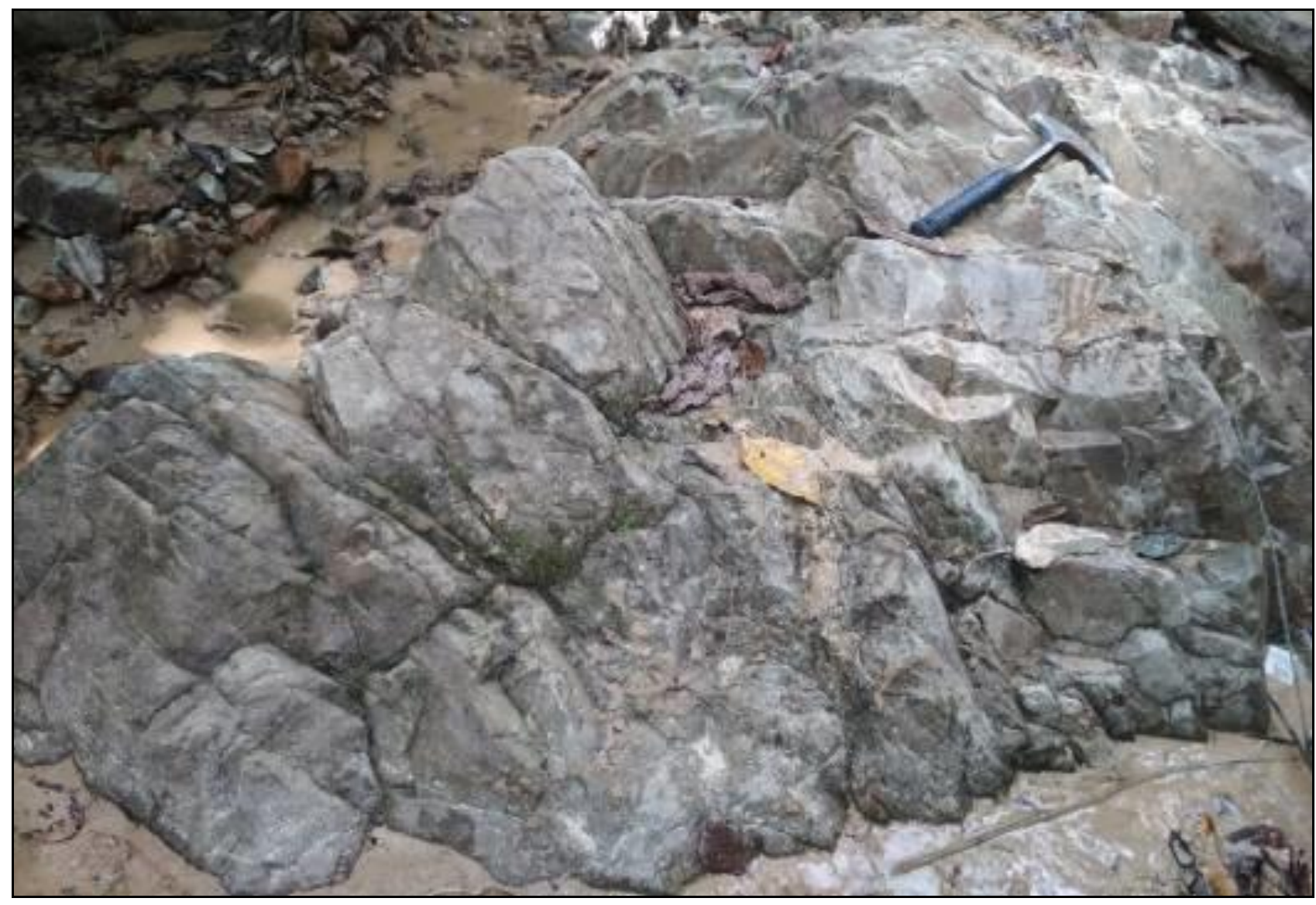

Gambar 8. Singkapan dan handspecimen satuan riodasit faneroporfiritik teralterasi chloritic
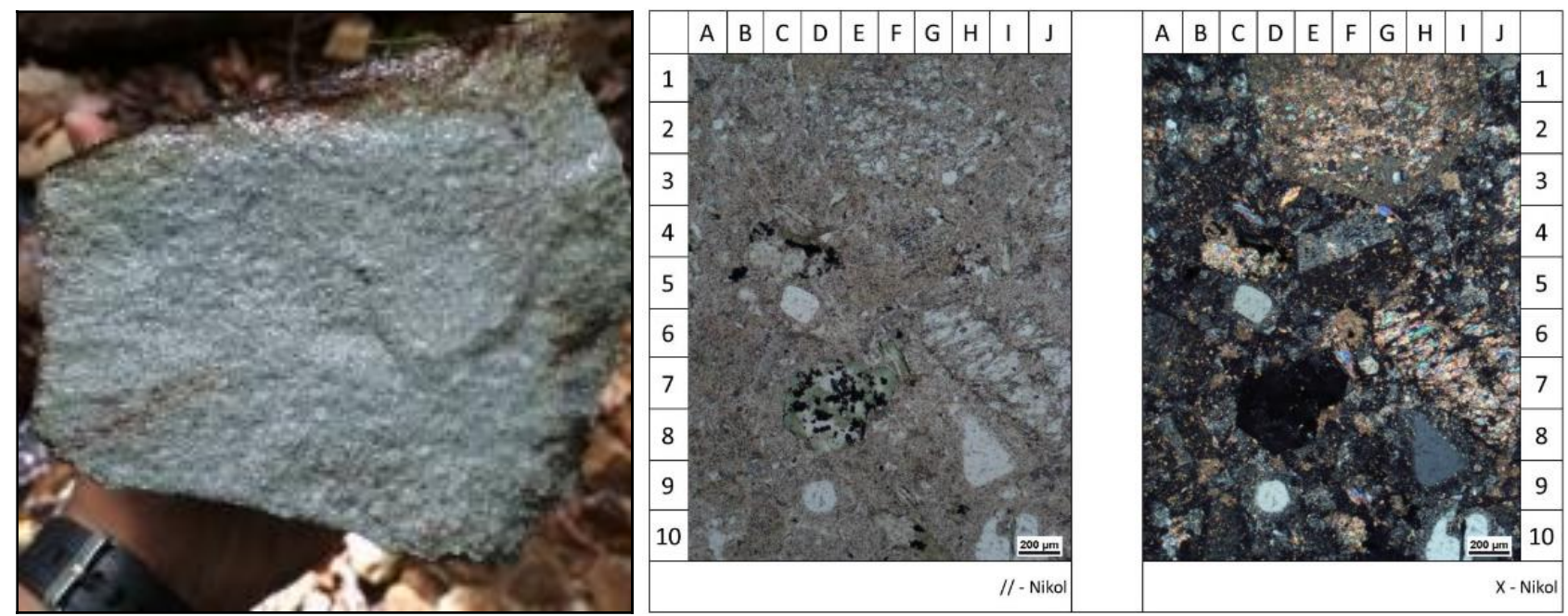

Gambar 9. Kenampakan mikroskopis riodasit faneroporfiritik yang telah teralterasi chloritic

Tabel 3. Hasil analisis Analytical Spectral Devices (ASD) sampel batuan teralterasi chloritic

\begin{tabular}{lllll}
\hline No. & Kode sampel & Mineral 1 & Mineral 2 & Mineral 3 \\
\hline 1 & 04.1.asd & Montmorilonite & Muscovitic-Phengitic & Chlorite \\
2 & 04.5.asd & Muscovitic & Chlorite & - \\
3 & 05.5.asd & Muscovitic-Phengitic & Chlorite & - \\
4 & 09.2.asd & Muscovitic-Phengitic & Chlorite & - \\
5 & 15.1.asd & Halloysite & Chlorite & Illite \\
6 & 15.2.asd & Muscovitic & Chlorite & Halloysite \\
7 & 16.3.asd & Phengitic & Chlorite & - \\
\hline
\end{tabular}




\subsection{Mineralisasi}

Mineral bijih pada daerah penelitian dijumpai pada stockwork urat kuarsa dan breksi hidrotermal. Urat kuarsa yang terbentuk pada daerah penelitian merupakan vuggy fracture urat kuarsa dengan komposisi kuarsa-oksida besi (hematit, geotit dan jarosit yang merupakan hasil oksidasi dari mineral silfida) dengan berbagai tekstur urat seperti drussy, sakaroidal, dogtooth, dan lattice bladed.

Pada stockwork urat kuarsa, mineralisasi terbentuk pada vuggy fracture berukuran $0.1-2 \mathrm{~mm}$ yang terisi oleh mineral silika dan sulfida. Mineral alterasi pada batuan samping berupa mineral lempung berwarna putih yang menggantikan mineral feldspar (Gambar 10 \& 11). Permukaan batuan telah lapuk (abu-abu kecoklatan), karena banyaknya rekahan pada permukaan batuan.

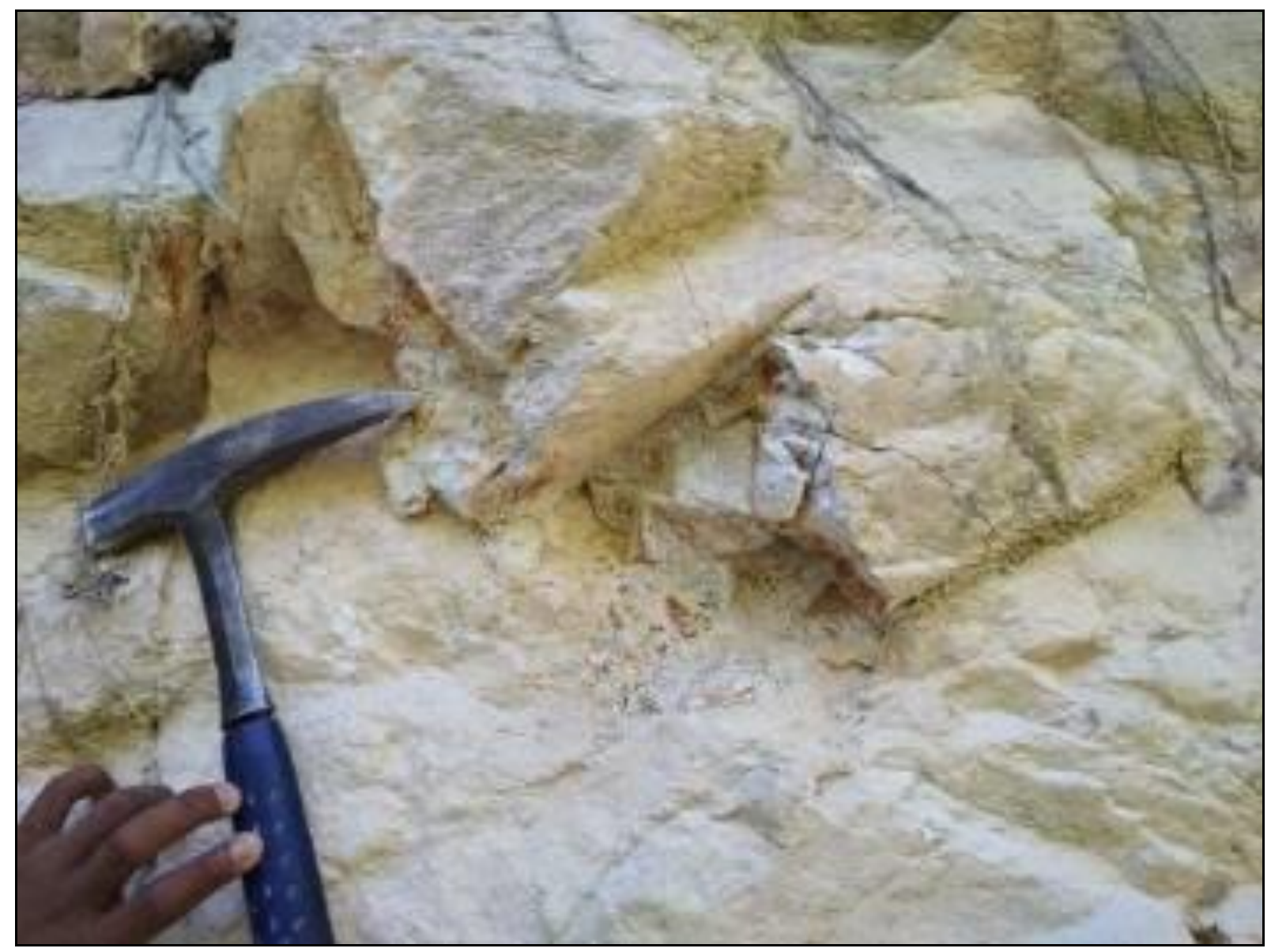

Gambar 10. Singkapan batuan riodasit termineralisasi stockwork urat kuarsa

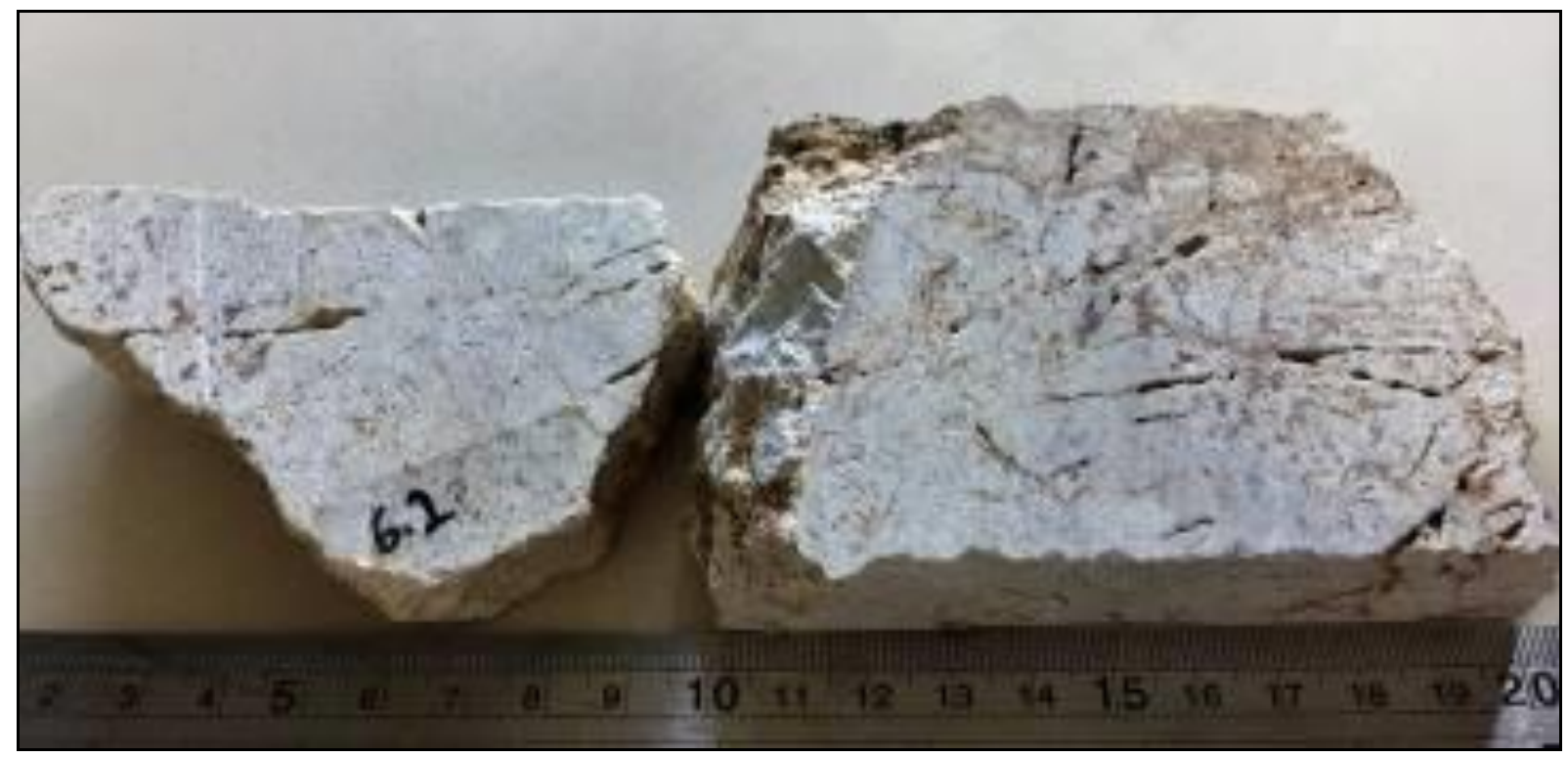

Gambar 11. Sampel hand speciment stockwork memperlihatkan tekstur vuggy fractures yang terisi oleh 

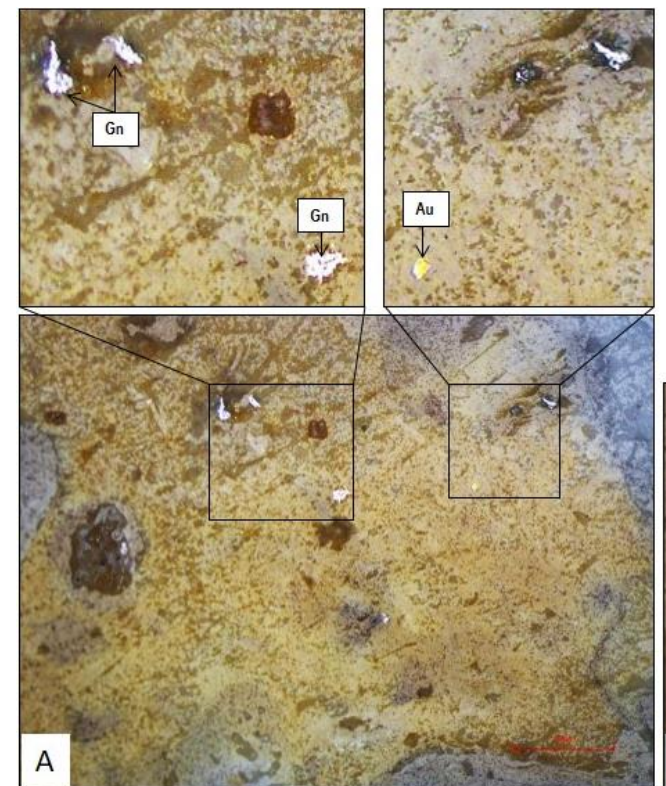
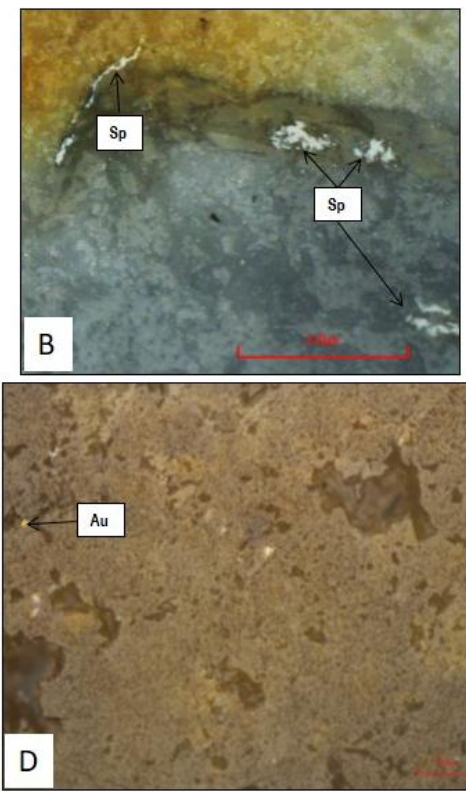
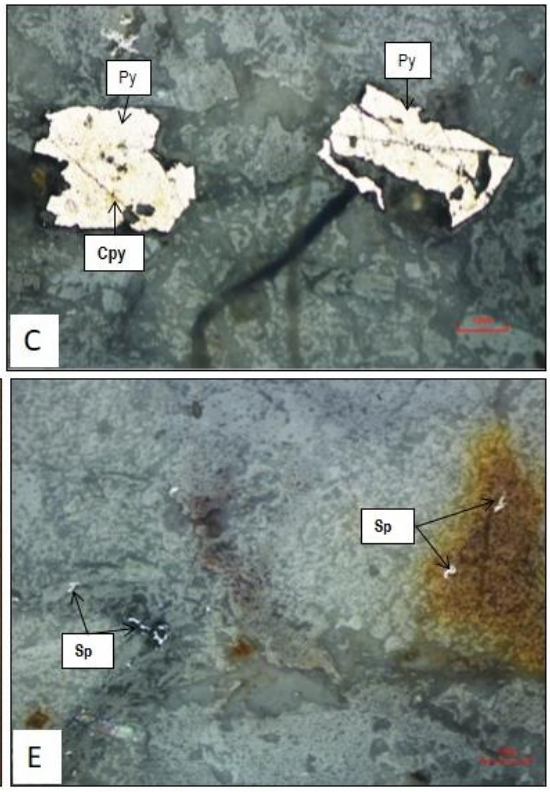

Gambar 12. Foto mikroskopis sayatan poles stockwork. A. Mineral galena dan emas; B. Mineral spalerit irregular; C. Mineral pirit subhedral tergantikan sebagian oleh kalkopirit; D. Mineral emas E. Sebaran mineral spalerit yang berukuran sangat halus

Berdasarkan hasil pengamatan mineragrafi sayatan poles pada stockwork urat kuarsa tampak mineral bijih yang terdiri dari pirit, kalkopirit, galena, spalerit, dan emas dengan tekstur mineralisasi pada umumnya merupakan tekstur penggantian, intergrowth, dan sedikit diseminasi (Gambar 12). Mineral Bijih berukuran sangat halus $01-05 \mu \mathrm{m}$, kecuali pirit yang ditemukan berukuran hingga $100 \mu \mathrm{m}$.

Breksi hidrotermal teramati pada daerah Totimbuale South, tepatnya pada lokasi tambang emas tradisional masyarakat. Breksi hidrotermal ini ditandai dengan kehadiran urat kuarsa berukuran besar dengan tekstur sakaroidal, drussy, serta lattice bladed yang saling berpotongan dan membentuk struktur berupa breksi hidrotermal dengan fragmen berupa batuan riodasitik yang berasosiasi dengan mineral sulfida dan oksida besi (Gambar 13). Breksi hidrotermal ini sulit diamati dikarenakan tingkat pelapukan dan oksidasi yang tinggi.

Berdasarkan pengamatan mineragrafi yang dilakukan, secara keseluruhan mengandung mineral bijih dengan tekstur, intergrowth, dan penggantian/replacement dan sedikit diseminasi. Mineral bijih yang tampak berupa mineral sulfida pirit, kalkopirit, arsenopirit, galena, spalerit, emas, dan elektrum (Gambar 14).
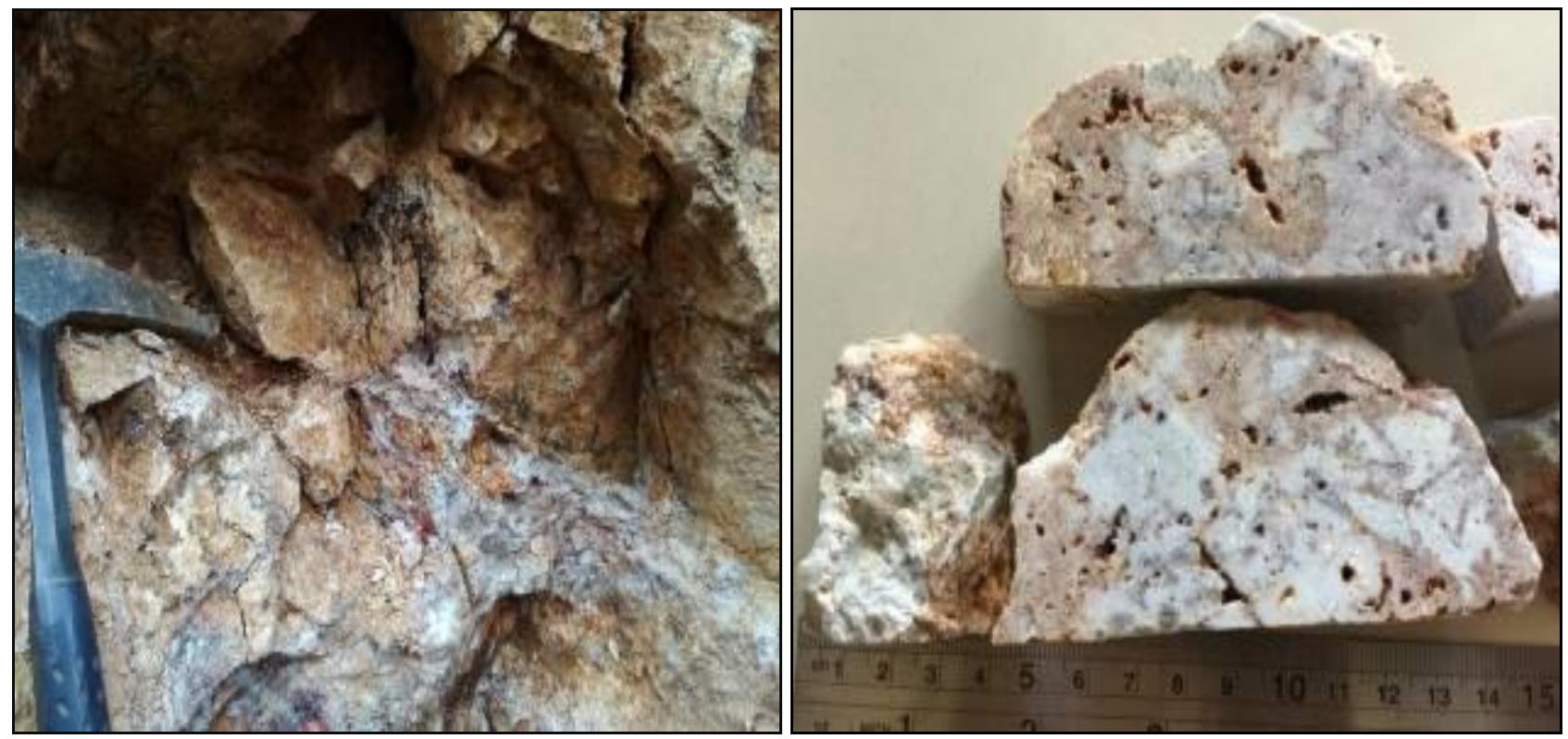

Gambar 13. Singkapan breksi hidrotermal pada lokasi pertambangan masyarakat (kiri) dan sampel hand specimen (kanan) yang memperlihatkan tekstur breksi dan vuggy fracture 

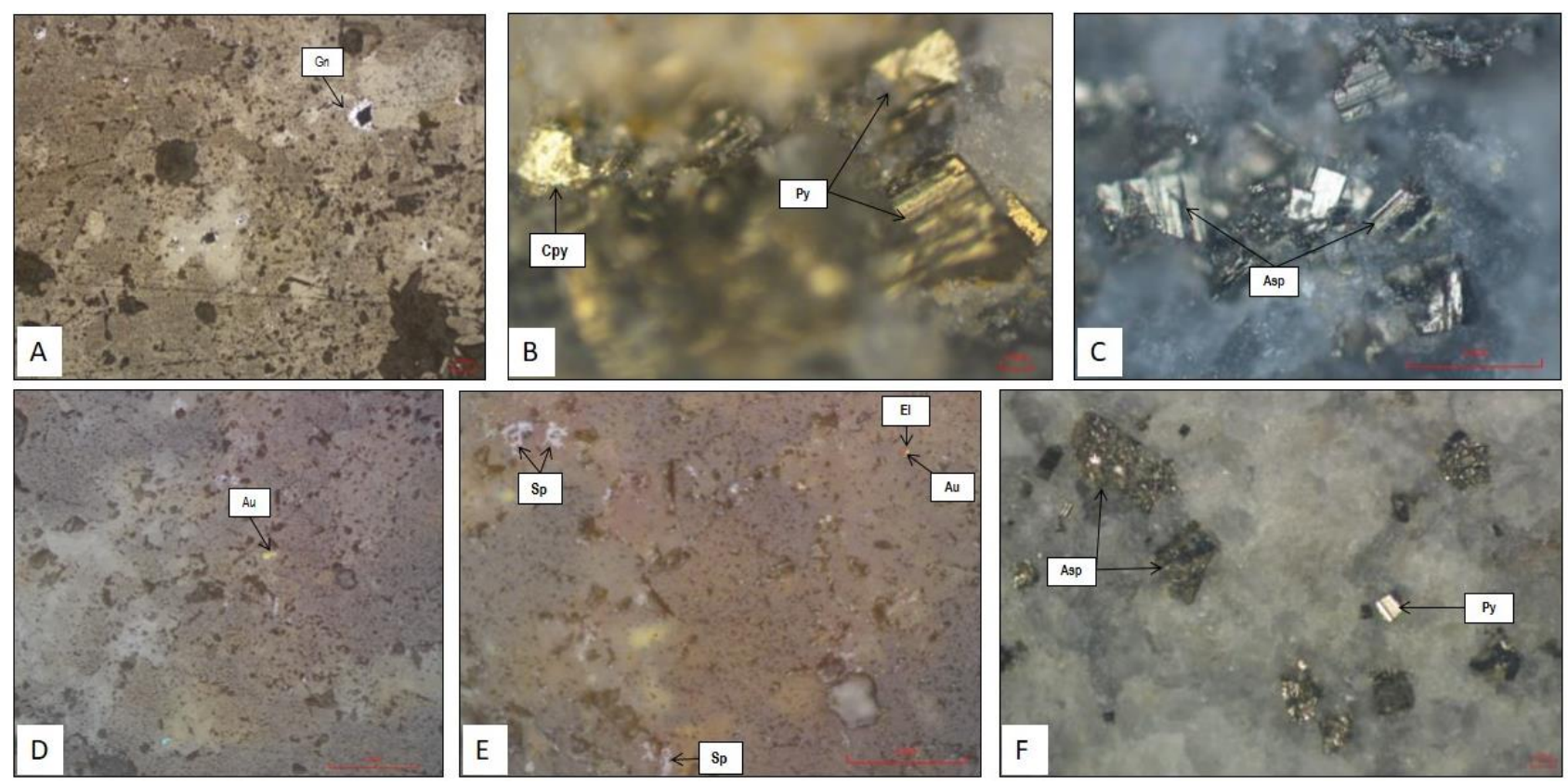

Gambar 14. Foto mikroskopis sayatan poles breksi hidrotermal. A. Mineral galena yang berasosiasi dengan mineral gangue; B. Mineral pirit yang mengisi vuggy fracture yang sebagian tergantikan oleh mineral kalkopirit; C. Mineral arsenopirit yang dicirikan dengan kembaran lamellar; D. Mineral emas; E. Mineral emas dan elektrum yang membentuk ikatan kompleks serta kenampakan mineral spalerit; F. Mineral arsenopirit dan pirit yang mengisi vuggy fracture

\subsection{Kontrol Geologi Terhadap Alterasi Dan Mineralisasi}

Tatanan geologi pada daerah penelitian sangat berpengaruh terhadap sistem mineralisasi ataupun distribusi mineral bijih. Sistem mineralisasi pada daerah penelitian dikontrol oleh dua faktor utama, yaitu faktor litologi dan kehadiran struktur geologi yang berkembang. Satuan riodasit pada daerah penelitian yang memiliki tekstur faneroporfiritik serta satuan granodiorit yang memiliki tekstur faneritik, memiliki potensi permeabilitas yang lebih baik bila dibandingkan dengan tekstur porfiroafanitik dari satuan riodasit porfiroafanitik. Hal ini dikarenakan secara umum tekstur faneroporfiritik dan faneritik memiliki ukuran kristal yang lebih besar bila dibandingkan dengan tekstur porfiroafanitik yang memiliki massa dasar afanitik. Satuan breksi diatrema pada daerah penelitian memiliki potensi permeabilitas yang paling tinggi dibandingkan dengan litologi lainnya, hal ini dikarenakan perbedaan ukuran fragmen dan matriks yang signifikan, sehingga kehadiran breksi diatrema menjadi penting untuk diperhatikan karena mineralisasi akan hadir pada matriks batuan.

Faktor kontrol litologi terlihat jelas dari penyebaran alterasi filik dan argilik yang dominan berkembang pada satuan riodasit dan breksi diatrema dikarenakan mempunyai permeabilitas yang tinggi. Mineralisasi pada daerah penelitian juga diinterpretasikan dikontrol oleh mekanisme vulkanik. Indikasi tersebut didasarkan pada penyebaran mineralisasi yang secara dominan menyusun satuan riodasit faneroporfiritik dan breksi diatrema, sementara pada satuan riodasit porfiroafanitik jarang ditemui urat mineralisasi. Kontrol vulkanik kemungkinan tidak hanya sebagai host rock mineralisasi saja, tetapi lebih ke arah sistem endapan secara umum yang berasosiasi dengan struktur sub-sirkular vulkanik/kaldera.

Kehadiran struktur geologi menambah nilai permeabilitas batuan karena dapat menjadi jalur yang baik bagi fluida hidrotermal sehingga dapat masuk melalui jaringan rekahan batuan tersebut. Struktur geologi yang berkembang pada daerah penelitian adalah sesar-sesar geser oblique berjenis normal right slip fault dan normal left slip fault (Rickard, 1972). Normal right slip fault berarah E-W diinterpretasikan sebagai struktur pre-mineralisasi atau struktur yang terbentuk sebelum proses alterasi dan mineralisasi, sedangkan normal left slip fault berarah NNE-SSW diinterpretasikan sebagai struktur syn-mineralisasi atau struktur yang mengontrol selama proses alterasi dan mineralisasi.

Sesar geser atau slip fault merupakan jenis struktur yang sangat baik dalam hubungannya terhadap distribusi alterasi dan mineralisasi, karena sifatnya yang transpression atau jenis struktur yang mengerut ke bawah permukaan dan membuat ore shot yang bersifat vertikal sebagai jalur fluida hidrotermal naik membentuk alterasi dan mineralisasi (Corbett, 2002). Kompleksitas struktur tersebut menambah nilai permeabilitas batuan menjadi lebih tinggi. 


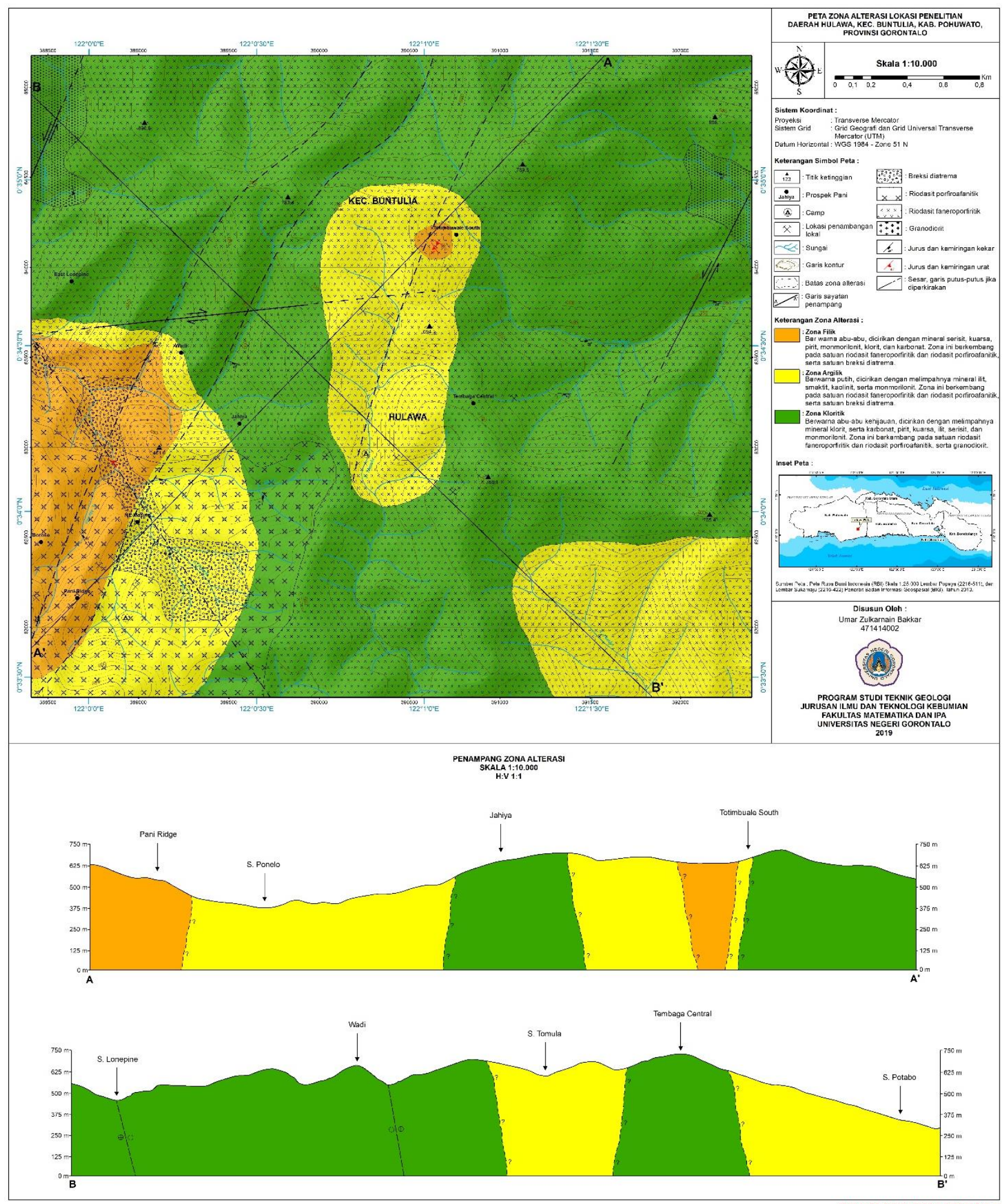

Gambar 15. Peta zona alterasi daerah penelitian

Daerah penelitian berasosiasi dengan struktur sub-sirkular vulkanik berupa kaldera. Menurut Sadewo \& Setiadji (2018), struktur ini diinterpretasikan terbentuk dari kompleksitas struktur Gorontalo Shear System (GSS) yang merupakan strain dari subduksi berarah WNW-ESE yang berada memanjang di bagian utara dari Lengan Utara Sulawesi yang menghasilkan fase ekstensional serta mengakibatkan proses realese ke arah selatan. Kehadiran kubah lava menjadi salah satu bukti dari keterdapatan sistem vulkanik yang dulunya pernah terbentuk pada Lengan Utara Sulawesi. Kehadiran struktur yang berkembang sekarang membentuk suatu sistem hidrotermal yang membentuk tipe endapan berupa epitermal sulfidasi rendah yang berasosiasi dengan kehadiran kubah lava (Sadewo \& Setiadji, 2018). 


\subsection{Karakteristik dan Tipe Endapan}

Alterasi dan mineralisasi hidrotermal yang berkembang pada daerah penelitian telah mengalami proses yang cukup intensif yang terdiri dari zona alterasi filik, zona alterasi argilik, serta zona alterasi chloritic yang dicirikan dengan himpunan mineral ubahannya. Sistem hidrotermal yang berkembang merupakan fase yang kompleks yang diduga terjadi proses overprinting antar zona alterasi. Proses tersebut terlihat dari hasil analisa mineral ubahan yang terbentuk pada daerah penelitian menunjukkan komposisi yang dapat dikelompokkan berdasarkan zona $\mathrm{pH}$ tertentu namun berbeda dalam dari segi temperatur pembentukannya.

Penentuan tipe endapan epitermal didasarkan pada beberapa karakteristik (Hedenquist, et al. 2000). Karakteristik dari tipe endapan epitermal dapat dilihat dari host rock, tekstur mineral bijih, alterasi batuan dan mineral sulfida yang dominan dijumpai. Berdasarkan klasifikasi tersebut dapat dilihat bahwa daerah penelitian memiliki batuan induk berupa batuan riodasitik, granodiorit dan breksi diatrema bersifat kalk-alkali, dengan tekstur bijih yang dijumpai berupa tekstur intergrowth, penggantian/replacement dan diseminasi minor. Alterasi yang berkembang pada daerah penelitian merupakan tipe alterasi yang setara dengan alterasi filik yang dicirikan dengan kehadiran serisit, kuarsa, pirit, monmorilonit, dan klorit, diikuti semakin kearah luar merupakan alterasi argilik yang dicirikan dengan himpunan mineral illit, smektit, kaolinit, dan monmorilonit, serta zona alterasi terluar pada lokasi penelitian yakni zona chloritic yang dicirikan dengan himpunan mineral klorit, karbonat, pirit, kuarsa, illit, serisit, monmorilonit.

Mineral bijih yang ditemukan pada daerah penelitian didasarkan pada pengamatan lapangan serta analisis mineragrafi berupa pirit, kalkopirit, arsenopirit, hematit, geotit, limonit, galena, spalerit, emas, dan elektrum. Pembentukan mineralisasi secara umum dijumpai pada sepanjang stockwork urat kuarsa, breksi hidrotermal, dan diseminasi (minor).Tekstur urat yang dijumpai pada daerah penelitian berupa drussy, sakaroidal, dogtooth, dan lattice bladed. Atas dasar tersebut peneliti mengklasifikasikan daerah penelitian termasuk kedalam tipe endapan epitermal sulfidasi rendah (Tabel 4). Tipe endapan epitermal ini juga didukung oleh peneliti terdahulu yang benyebutkan bahwa daerah prospek Gunung Pani masuk pada tipe endapan epitermal sulfidasi rendah dengan kadar emas yang rendah (Kavalieris, 1984).

Mengacu pada tabel karakteristik endapan epitermal sulfidasi rendah yang dibuat oleh Hedenquist, et al,. (2000) dan Sillitoe \& Hedenquist (2003), maka dapat diketahui bahwa endapan epitermal sulfidasi rendah pada daerah penelitian merupakan tipe endapan epitermal sulfidasi rendah yang berkembang pada kedalaman 300-500 meter. Hal tersebut ditentukan berdasarkan adanya kesesuaian terhadap beberapa karakteristik endapan epitermal sulfidasi rendah pada daerah penelitian seluruhnya

Tabel 4. Perbandingan karakteristik endapan epitermal sulfidasi rendah menurut Hedenquist et al., (2000) dengan daerah penelitian

\begin{tabular}{|c|c|c|}
\hline Karakteristik & Epitermal sulfidasi rendah ${ }^{a}$ & Daerah penelitian \\
\hline Alterasi & $\begin{array}{l}\text { - } \mathrm{pH} \text { netral } \\
\text { - Urutan alterasi: silisifikasi - serisit - argilik - } \\
\text { propilitik }\end{array}$ & Filik - Argilik - Chloritic \\
\hline Asosiasi Mineral & $\begin{array}{l}\text { Dominan pirit, spalerit, galena, galena, } \\
\text { kalkopirit, arsenopirit, elektrum, emas }\end{array}$ & $\begin{array}{l}\text { Dominan pirit, spalerit, } \\
\text { galena, emas }\end{array}$ \\
\hline Bijih & $\mathrm{Au}-\mathrm{Ag}, \mathrm{Pb}, \mathrm{Cu}, \mathrm{Zn}$ & $\mathrm{Au}-\mathrm{Ag}, \mathrm{Pb}, \mathrm{Cu}$ \\
\hline $\begin{array}{l}\text { Pembentukan } \\
\text { mineralisasi }\end{array}$ & $\begin{array}{l}\text { - Terdapat disepanjang urat } \\
\text { - Jarang diseminasi } \\
\text { - Dominan stockwork }\end{array}$ & $\begin{array}{l}\text { Terdapat disepanjang urat } \\
\text { - Stockwork } \\
\text { - Breccia } \\
\text { - Diseminasi (minor) }\end{array}$ \\
\hline Struktur & $\begin{array}{l}\text { - Rekahan dengan kedalaman tinggi } \\
\text { - Breksi magmatik-hidrotermal, breksi diatrema }\end{array}$ & $\begin{array}{l}\text { - Struktur Breksi } \\
\text { hidrotermal, breksi } \\
\text { diatrema }\end{array}$ \\
\hline Tekstur urat & $\begin{array}{l}\text { - Sisir, drusy, sakaroidal, bladed, krustiform, } \\
\text { kolloform } \\
\text { - Urat breksi }\end{array}$ & $\begin{array}{l}\text { Drussy, sakaroidal, bladed, } \\
\text { breccia }\end{array}$ \\
\hline
\end{tabular}


pada batuan induk berupa riodasitik dengan afinitas kalk-alkalin, mineral bijih terutama emas dan elektrum yang terendapkan pada stockwork urat kuarsa, terdesiminasi pada batuan serta breksi hidrotermal, keterdapatan mineral lempung sebagai penciri dari ketiga zona alterasi pada daerah penelitian, mineral sulfida pada daerah penelitian yang umumnya merupakan mineral yang berasosiasi dengan logam dasar berupa pirit, kalkopirit, arsenopirit, galena, dan spalerit.

Pemodelan endapan epitermal sulfidasi rendah pada daerah penelitian mengacu pada model epitermal oleh Berger \& Eimon, dalam Pirajno (2009). Berdasarkan himpunan mineral bijih pada daerah penelitian yang berupa kalkopirit, arsenopirit, galena, spalerit, emas, dan elektrum, beserta keterdapatan mineral pengotor berupa pirit dan kuarsa, serta kehadiran stockwork dan breksi hidrotermal bertekstur kristalin kuarsa-kalsit, maka dapat diketahui bahwa endapan epitermal sulfidasi rendah pada daerah penelitian berada pada zona interval logam dasar.

Proses boiling dan mixing yang berperan terhadap presipitasi mineral bijih pada daerah penelitian, selain dibuktikan oleh asosiasi urat kuarsa terhadap zona alterasi filik, argilik, dan chloritic, baik secara langsung maupun tidak langsung. Selain kedua proses tersebut, keterdapatan mineral bijih yang terdesiminasi menjadi salah satu bukti keterdapatan proses presipitasi mineral bijih akibat adanya sulfidasi pada batuan samping.

Berdasarkan data-data di atas, daerah penelitian masuk ke dalam model epitermal sulfidasi rendah pada tipe open-vein dan breccia oleh Berger \& Eimon, dalam Pirajno (2009). Tipe ini sangat dikontrol oleh struktur/rekahan yang membentuk urat/vein, kadar rendah dari urat breksi hidrotermal, stockwork, diseminasi pada bagian atas dari sistem ini.

Berdasarkan karakteristik alterasai serta mineralisasi terutama dijumpainya jenis mineral bijih emas dan elektrum serta mineral bijih sulfida yang berasosiasi dengan jenis logam dasar, maka daerah penelitian berada pada tipe epitermal sulfidasi rendah yang berkembang pada kedalaman yang 300$500 \mathrm{~m}$ sesuai dari tipe open-vein dan breccia.

\section{Kesimpulan}

Geologi daerah penelitian tersusun atas litologi granodiorit berumur Oligosen dan satuan riodasit bertekstur faneroporfiritik dan porfiroafanitik, serta breksi diatrema berumur Pliosen yang berperan sebagai batuan induk bagi mineralisasi bijih. Struktur geologi yang berkembang pada daerah penelitian adalah sesar-sesar oblique berjenis normal right slip fault dan normal left slip fault. Normal right slip fault berarah E-W diinterpretasikan sebagai struktur pre-mineralisasi, sedangkan normal left slip fault berarah NNE-SSW diinterpretasikan sebagai struktur sin-mineralisasi atau struktur yang mengontrol selama proses alterasi dan mineralisasi.

Alterasi yang berkembang pada daerah penelitian yakni zona filik (serisit + kuarsa \pm pirit \pm monmorilonit \pm klorit \pm karbonat), zona argilik (ilit + kaolinit \pm smektit \pm monmorilonit), zona chloritic (klorit + karbonat + pirit \pm kuarsa \pm ilit \pm serisit \pm monmorilonit). Mineralisasi pada daerah penelitian dijumpai pada stockwork urat kuarsa dan breksi hidrotermal dan beberapa ditemui secara diseminasi. Mineral bijih dengan tekstur intergrowth, penggantian/replacement serta diseminasi minor yang terdiri dari pirit, kalkopirit, arsenopirit, galena, spalerit, emas, dan elektrum.

Karakteristik tipe endapan hidrotermal pada daerah penelitian berupa endapan epitermal sulfidasi rendah. Proses mineralisasi dikontrol oleh proses tektonik berupa patahan-patahan yang menyediakan jalur fluida hidrotermal. Mineralisasi juga diindikasikan dikontrol oleh mekanisme vulkanik. Berdasarkan karakteristik alterasi dan mineralisasinya, endapan epitermal pada daerah penelitian merupakan tipe endapan epitermal sulfidasi rendah pada level dengan kedalaman (300-500m) dengan model endapan tipe open-vein dan breccia.

\section{Ucapan Terima Kasih}

Penelitian ini dapat terlaksana atas dukungan dari PT. Gorontalo Sejahtera Mining dan Universitas Negeri Gorontalo. Peneliti juga mengucapkan banyak terimakasih kepada seluruh pihak yang tidak dapat disebutkan satu persatu yang telah membantu dalam penyelesaian penelitian ini.

\section{Referensi}

[BIG] Badan Informasi Geospasial. (2013). Peta Rupa Bumi Indonesia, Lembar Sukamaju dan Lembar Popaya, Skala 1:25.000. Bogor. 
Carlile J. C., Digdowirogo, S., dan Darius, K. (1990). Geological Setting, Characteristics and Regional Exploration for Gold in the Volcanic Arcs of North Sulawesi, Indonesia. Journal of Geochemical Exploration, 35 (1990). Hal. 105-140, Elsevier Science Publishers B. V., Amsterdam - Printed in the Netherlands.

Corbett, G.J. (2002). Epithermal Gold for Explorationists. Australian Institute of Geoscientists Presidents Lecture: AIG News No. 67, 8p.

Hedenquist, J.W., Arribas, A. R., dan Urien E. G. (2000). Exploration for Epithermal Gold Deposits. Economic Geology. Vol. 13 p. 245-227.

Kavalieris, I., (1984), The Geology and Geochemistry of The Gunung Pani Gold Prospect, North East Sulawesi, Indonesia. Australian National University

Pirajno, F. (1992). Hydrothermal Mineral Deposits: Principles and Fundamental Concepts for the Exploration Geologist. Afrika Selatan: Springer-Verlag

Pirajno, F. (2009). Hydrothermal Process and Mineral Systems. Springer-Verlag, Perth. Heidelberg.

Rickard. (1972). Classification of Translational Fault Slip. Geological Society of America.

Sadewo, C., Setiadji, D. L., (2018). Geologi, Alterasi dan Mineralisasi Emas pada Tipe Endapan Epitermal Sulfidasi Rendah di Prospek X, Gunung Pani, Kabupaten Pohuwato, Provinsi Gorontalo. In Proceeding of UGM. 728p. Indonesia: Seminar Nasional Kebumian Ke-11.

Sillitoe, R.H., Hedenquist, J.W., (2003). Linkages between Volcanotectonic Settings, Ore-Fluid Compositions, and Epithermal Precious Metal Deposits. Society of Economic Geologist, Special Publication 10: London.

Van Zuidam, R.A, (1985), Aerial Photo Interpretation in Terrain Analysis and Geomorphologic Mapping. Smith Publisher The Hugue. ITC. 